\title{
Cognitive Behavioral Therapy Treatment for Reducing Stress: A Case Study of Self-Acceptance in an Early Adult College Student
}

\section{Patricia Evelyn Pasaribu a and Miranda D. Zarfiel ${ }^{\mathrm{b}}$}

a Department of Educational Psychology, Faculty of Psychology, Universitas Indonesia, Depok, Indonesia; ${ }^{b}$ Department of Educational Psychology, Faculty of Psychology, Universitas Indonesia, Depok, Indonesia

*Corresponding Authors:

Miranda D. Zarfiel

Department of Educational Psychology

Faculty of Psychology, Universitas Indonesia

Depok, Indonesia 


\title{
Cognitive Behavioral Therapy Treatment for Reducing Stress: A Case Study of Self-Acceptance in an Early Adult College Student
}

\begin{abstract}
Psychological stress is a state where a person's circumstances are seemingly beyond the person's ability to handle and threatens the well-being of self or others. The current research focuses on student stress. The participant reported stress symptoms which were affecting her ability to maintain focus while doing tasks and interfered with her self-motivation and learning performance. The participant's problems seemed to indicate a lack of self-acceptance. She evidenced false perceptions of herself and society, and this produced negative cognitions, emotions, and behaviors. Changing the participant's false perceptions will, therefore, help reduce negative stress response patterns. Cognitive behavioral therapy was shown to be an effective treatment for stress. This single-subject design case study examines the effectiveness of CBT treatment for improving self-acceptance and decreasing a negative stress response in a 20-year-old female college student. The research used a three-stage assessment design: pretest, intervention, posttest. The intervention consisted of four 120-min sessions and two follow-ups. The effectiveness of the intervention was determined using a behavioral checklist, a pretest, and a posttest. The results showed an improvement in the participant's self-acceptance. The participant's stress responses decreased, and she had thoughts about herself and her world that improved her emotions and behaviors.
\end{abstract}

Keywords: cognitive behavioral therapy, self-acceptance, student stress, college stress

\section{Introduction}

Early adult students who choose to continue their education through higher education face challenges that they may interpret as constant demands to be executed. Although students are often able to adjust to overwhelming challenges, if there are demands that exceed their abilities, it can lead to stress (Dexter, Huff, Rudecki, \& Abraham, 2018). Psychological stress happens when people feel overwhelmed by demands that are beyond their ability to fulfill (Brecht, 2000).

Stress can affect many aspects of a person. It can decrease a person's physical, emotional, and psychological well-being as well as impede the body's functions, hinder adjustment to additional change and stressors, and increase the risk of illness (Pitt, Oprescu, Tapia, \& Gray, 2017). Psychological symptoms such as depression and anxiety in college students may point to an overabundance of stressors in their lives. Moreover, stress often affects academic performance and may lead to mental health problems, substance abuse, and other negative behaviors (Dy, Espiritu-Santo, Ferido, \& Sanchez, 2015; Pariat, Rynjah, \& Kharjana, 2014).

However, the situation that caused stress depends on the perspective and judgments about the situation (Handayani, 2004). The individual's judgment of a distressing experience is better understood via cognitive appraisal, which in turn influences their emotional reactions (Straud $\&$ McNaughton-Cassill, 2018). Past experiences, environment, and motivation are factors that 
influence the cognition process. In college students, not only earning high grades but also relations with faculty members, time pressure, relationships with family and friends, eating and sleeping habits, and loneliness are the source of stress (Ross, Niebling, \& Heckert, 1999).

Stress response in the form of anxiety is influenced by self-acceptance (Hurlock, 1974). It may be that when people become psychologically distressed, they engage in conditional selfacceptance thinking. Conversely, unconditional self-acceptance means the individual fully and unconditionally accepts himself/herself whether or not he/she behaves intelligently, correctly, or competently and whether or not other people approve, respect, or love him/her (Chamberlain \& Haaga, 2001). People who accept themselves unconditionally have the ability to socialize (Powell, 1992). Therefore, they have a higher chance to adapt to their surroundings (Pramono \& Astuti, 2017).

Lower levels of unconditional self-acceptance were associated with increased levels of depression symptoms and anxiety and low levels of self-esteem, happiness, and life satisfaction in undergraduate students (Flett, Besser, Davis, \& Hewitt, 2003). From the above explanation, lack of self-acceptance can negatively affect the psychological well-being of college students, hence, the need for an intervention program to help solve their problems. Ellis (Macinnes, 2006) considered strengthening an individual's self-acceptance belief as the cornerstone of psychological well-being. Developing unconditional self-acceptance allows the individuals with psychological health problems to accept themselves as fallible human beings who sometimes make mistakes. Thus, individuals do not think about other people's judgments against themselves (Widiantoro, 2015). Interventions designed to support and encourage more unconditional self-acceptance would therefore be helpful in improving the general psychological health.

There are a number of techniques that can be used to improve self-acceptance, including group interventions (Heriyadi, 2013) and individual counseling with reality approach (McGhee, 2016). There are also Self-Acceptance Training (SAT) and Acceptance and Integration Training (AAIT), wherein the participant experiences moments without interference from criticism, judgment, and self-evaluation (Warastri, 2017). Another technique that is proved to be effective for self-acceptance is cognitive behavioral therapy (CBT) (Branch \& Wilson, 2007; Cully \& Teten, 2008). CBT is a form of psychotherapy that focuses on individual cognitive and behavioral (Branch \& Wilson, 2007). The basic premise of CBT is that emotions are difficult to change directly, so CBT targets emotions by changing thoughts and behaviors that are contributing to the distressing emotions (Cully \& Teten, 2008). CBT proposed an ABC model as an initial assessment. This model has a premise; the antecedents of behavior include conditions or stimuli that set the occasion for the behavior to occur: behavior, which refers to a person's activity (can be thought and emotion), and consequences, which refer to the response or effect that the behavior creates (Cully \& Teten, 2008; Farmer \& Chapman, 2016). In addition, CBT also reduces and helps control physical symptoms developed during stress. It helps reduce an individual's physical and emotional symptoms that may be experienced when facing depressing situations (Cully \& Teten, 2016). This study is based on a single case in which the participant was a college student who 
experienced stress because of her lack of self-acceptance. It is important to provide intervention with CBT approach to improve her self-acceptance. Changing the participant's perception towards herself and others will help reduce the negative response that arose from stressful conditions. Regehr, Glancy, and Pitts (2013) also found that CBT was associated with decreased symptoms of anxiety and lower level of depression in college students. The CBT approach will allow the participant to have an understanding that she is not the only one responsible for the bad situations that happened but also others who are involved. Thus, this study examines the effectiveness of CBT approach in improving self-acceptance and reducing stress response in college students. The hypotheses of this study are as follows: (1) there is an increase of the participant's self-acceptance and (2) a decrease of the participant's stress responses after the intervention.

\section{Methods}

\section{Participant}

The participant in this study is a 20 -year-old female college student who was studying in fourth semester. Based on the initial assessments, the participant reported several stress symptoms, such as nausea and pain on her chest, when under stress. She often recalled her painful events in the past that made her feel negative emotions. These conditions affected her ability in maintaining focus while doing tasks and interfered with her motivation and learning performance; nevertheless, her intelligence was superior (IQ score $=120$ based on Wechsler Adult Intelligence Scale). This feeling began to emerge during the third semester of her undergraduate study. One of the triggers was her involvement in a conflict at her organization. She felt depressed because her performance was criticized by her supervisor. These conditions led her to seek treatment from the counseling center. The initial assessment shows that the participant's condition was caused by her lack of self-acceptance. She had a false perception towards herself and the society, resulting in her negative emotions and behavior towards others.

\section{Research Design}

This study used a single-subject design to observe the effect of an intervention program on a single participant (Gravetter \& Cleland, 2012). Furthermore, the research design used in this study is the ABA design. This design consists of three phases: baseline (A), treatment (B), and evaluation (A). The baseline phase was implemented at the beginning of the meeting, together with the first session of the intervention. In the intervention phase, a brief CBT approach was implemented for the participants in almost 3 weeks. At the end of the fourth session, a posttest was given to examine the effectiveness of the intervention in improving the participant's self-acceptance and reducing her stress response, through patterns of change before, during, and after intervention programs are provided. Prior to the intervention, informed consent was read, discussed, and signed by the participant.

\section{Measure and Materials}

In this study, we measure the effectiveness of each session and the overall program. In each session, the participant's behavior was measured by a behavioral checklist developed from 
the characteristics of self-acceptance by Chamberlain (1999) (see Table 1), whereas the stress response characteristics stated by Taylor (2012) were divided into physical, behavioral, emotional, and cognitive signs (see Table 2).

Table I. Self-Acceptance Characteristics

\section{Self-Acceptance Characteristics}

1. Belief that one's self-worth is bestowed by virtue of being human

2. Belief that no one is worth more than anyone else

3. Tendency to set goals based on a pursuit of intrinsic satisfaction and enjoyment rather than enhancement of self-worth

4. General avoidance of the tendency to self-rate

5. Objective awareness of one's strengths but without global appraisal on the basis of these strengths and limitations

6. Tendency to respond to failure and negative feedback with some unhappiness about thwarted goals, but not as indicative of lower self-worth

7. Tendency to respond to failure and negative feedback as informative about areas for behavioral improvement

8. Tendency to respond to success and positive feedback as informative as areas of strength, but not with a sense of being a better person because of success

9. Sense of self-worth independent of other's approval

10. General avoidance of the tendency to compare one's worth with others

Table II. Stress Response Characteristics

\begin{tabular}{l|l}
\hline \multicolumn{3}{c}{ Stress Response Characteristics } \\
\hline Physical response & $\begin{array}{l}\text { Involves the nervous system and endocrine } \\
\text { system (increase in blood pressure, heart rate, } \\
\text { pulse rate, skin conductivity, and respiratory } \\
\text { system) }\end{array}$ \\
Emotional \\
response \\
Cognitive response anxiety, enthusiasm, shame, anger, \\
depression, and denial \\
Lack of concentration and disturbances in the \\
cognitive processes (easily distracted, repetitive, \\
and irrelevant thoughts) \\
Fight (aggressive response to stress) or flight \\
(social withdrawal, withdrawal through drugs, \\
response
\end{tabular}

The researcher also measured the effectiveness of the entire program by scoring the pretest and posttest that composed from the indicator of success in each session. The questions used in the posttest were the same as the ones used in the pretest. Activity sheets and journals were used in the intervention to help identify the participant's emotions and thoughts. Details of indicators of program success are found in Table 3.

Table III. Success Indicators

\begin{tabular}{c|l|l}
\hline Session & \multicolumn{1}{|c|}{ Success Indicators } & \multicolumn{1}{c}{ Annotation } \\
\hline Session 1 & $\begin{array}{l}\text { The participant knows her } \\
\text { potential }\end{array}$ & $\begin{array}{l}\text { Score 0: The participant does not know her } \\
\text { potential } \\
\text { Score 1: The participant knows her potential } \\
\text { quite well } \\
\text { Score 2: The participant knows her potential } \\
\text { well }\end{array}$ \\
\hline
\end{tabular}




\begin{tabular}{|c|c|c|}
\hline & $\begin{array}{l}\text { The participant understands } \\
\text { her current conditions }\end{array}$ & $\begin{array}{l}\text { Score } 0 \text { : The participant does not understand her } \\
\text { current condition } \\
\text { Score 1: The participant understands her current } \\
\text { condition quite well } \\
\text { Score 2: The participant understands her current } \\
\text { condition well } \\
\text { Maximum score: } 4\end{array}$ \\
\hline \multirow[t]{2}{*}{ Session 2} & $\begin{array}{l}\text { The participant views herself } \\
\text { positively }\end{array}$ & $\begin{array}{l}\text { Score 0: The participant views herself negatively } \\
\text { Score 1: The participant views herself quite } \\
\text { positively } \\
\text { Score 2: The participant views herself positively }\end{array}$ \\
\hline & $\begin{array}{l}\text { The participant has a positive } \\
\text { thought about how other } \\
\text { people think about her }\end{array}$ & $\begin{array}{l}\text { Score } 0 \text { : The participant has a negative thought } \\
\text { about how other people think about her } \\
\text { Score 1: The participant has a quite positive } \\
\text { thought about how other people think about her } \\
\text { Score 2: The participant has a positive thought } \\
\text { about how other people think about her } \\
\text { Maximum score: } 4\end{array}$ \\
\hline \multirow[t]{2}{*}{ Session 3} & $\begin{array}{l}\text { The participant understands } \\
\text { the basic premise of CBT }\end{array}$ & $\begin{array}{l}\text { Score } 0 \text { : The participant does not understand the } \\
\text { basic premise of CBT } \\
\text { Score 1: The participant quite understands the } \\
\text { basic premise of CBT } \\
\text { Score 2: The participant understands the basic } \\
\text { premise of CBT }\end{array}$ \\
\hline & $\begin{array}{l}\text { The participant is aware of } \\
\text { her irrational thoughts to } \\
\text { herself and others }\end{array}$ & $\begin{array}{l}\text { Score 0: The participant is not aware of her } \\
\text { irrational thoughts in viewing herself and others } \\
\text { Score 1: The participant is quite aware of her } \\
\text { irrational thoughts in viewing herself and others } \\
\text { Score 2: The participant is aware of her } \\
\text { irrational thoughts in viewing herself and others } \\
\text { Maximum score: } 4\end{array}$ \\
\hline \multirow[t]{4}{*}{ Session 4} & $\begin{array}{l}\text { The participant has a relevant } \\
\text { and positive thought about } \\
\text { herself }\end{array}$ & $\begin{array}{l}\text { Score 0: The participant has a negative and } \\
\text { irrelevant thought about herself } \\
\text { Score 1: The participant has a quite relevant and } \\
\text { positive thought about herself } \\
\text { Score 2: The participant has a relevant and } \\
\text { positive thought about herself }\end{array}$ \\
\hline & $\begin{array}{l}\text { The participant has a relevant } \\
\text { and positive thought towards } \\
\text { others }\end{array}$ & $\begin{array}{l}\text { Score 0: The participant has a negative and } \\
\text { irrelevant thought towards others } \\
\text { Score 1: The participant has a negative and } \\
\text { irrelevant thought towards others } \\
\text { Score 2: The participant has a relevant and } \\
\text { positive thought towards others }\end{array}$ \\
\hline & $\begin{array}{l}\text { The participant feels more } \\
\text { positive about herself }\end{array}$ & $\begin{array}{l}\text { Score 0: The participant feels negative about } \\
\text { herself } \\
\text { Score 1: The participant feels quite positive } \\
\text { about herself } \\
\text { Score 2: The participant feels positive about } \\
\text { herself }\end{array}$ \\
\hline & The participant is motivated & Score 0: The participant does not feel motivated \\
\hline
\end{tabular}




\begin{tabular}{l|l|l}
\hline to solve her current problems & $\begin{array}{l}\text { to solve her current problems } \\
\text { Score 1: The participant is quite motivated to } \\
\text { solve her current problems } \\
\text { Score 2: The participant is very motivated to } \\
\text { solve her current problems } \\
\text { Maximum score: } 8 \\
\text { Maximum total score: } \mathbf{2 0}\end{array}$ \\
\hline
\end{tabular}

\section{Procedures}

To design the intervention program, we did a literature review arranged based on the participant's problems, and the intervention program is based on Cully and Teten's (2008) therapist's guide. The guide uses brief CBT which compresses treatment down from 12 to 20 sessions to 4 to 8 sessions. The researcher offered treatment with a brief CBT approach to the participant after considering that as a college student, the participant likely already had a lot of scheduled regular academic and nonacademic activities. The participant had limited free time to participate in a longer therapy session. The main targets of the intervention were (1) identifying the participant's self-potential and self-judgment, (2) recognizing the participant's false perceptions about herself and her social environment, and (3) getting the participant to change her perceptions to being more realistic and positive. The first intervention session started with a pretest, and then we discussed the participant's goals for the program. During the initial intervention session, the participant was asked to complete the activity sheets to identify her emotions and thoughts. At the end of each session, the participant was asked to write a journal about her insights. The posttest was given at the end of the fourth session. The questions used in the posttest were the same as the ones used in the pretest. All intervention sessions were conducted in the Teaching Clinic, Faculty of Psychology, at Universitas Indonesia. Details of the program are shown in Table 4.

Table IV. Details of the Program

\begin{tabular}{|c|c|c|}
\hline Purpose & Session & Activity \\
\hline \multirow[t]{2}{*}{$\begin{array}{l}\text { Identifying self-potential } \\
\text { and self-judgments }\end{array}$} & Session 1 & $\begin{array}{l}\text { Initial assessment results and the participant's } \\
\text { target } \\
\text { Program information } \\
\text { "Journal of the Day" (insights from the session) }\end{array}$ \\
\hline & Session 2 & $\begin{array}{l}\text { Positive and Negative Self-Statements } \\
\text { Positive affirmations } \\
\text { "Journal of the day" }\end{array}$ \\
\hline \multirow{2}{*}{$\begin{array}{l}\text { Recognizing false } \\
\text { perceptions about the self } \\
\text { and the social } \\
\text { environment }\end{array}$} & Session 3 & $\begin{array}{l}\text { ABC activity sheet (identify antecedents, } \\
\text { behavior, and consequences) } \\
\text { Psychoeducation about CBT approach }\end{array}$ \\
\hline & & $\begin{array}{l}\text { Dysfunctional Thought Record (DTR)-part } 1 \\
\text { (identify her automatic thoughts) } \\
\text { "Journal of the Day" }\end{array}$ \\
\hline \multirow[t]{2}{*}{$\begin{array}{l}\text { Changing perceptions to } \\
\text { become more realistic } \\
\text { and positive }\end{array}$} & Session 4 & $\begin{array}{l}\text { Dysfunctional Thought Record (DTR)-part } 2 \\
\text { (alternative thoughts to the participant's negative } \\
\text { automatic thoughts) } \\
\text { Discuss the DTR results } \\
\text { "Problem Solved!" (concrete steps to solve the } \\
\text { participant's problems) }\end{array}$ \\
\hline & & "My Commitment" (the participant's commitment \\
\hline
\end{tabular}




\begin{tabular}{l|l|l}
\cline { 2 - 3 } & & $\begin{array}{l}\text { to herself and others) } \\
\text { Relaxation Techniques (absorption technique and } \\
\text { deep breathing) }\end{array}$ \\
\hline $\begin{array}{l}\text { Maintaining progress } \\
\text { after the completion of } \\
\text { the intervention program }\end{array}$ & Follow-up 1 & $\begin{array}{l}\text { Discuss her conditions and emotions after the } \\
\text { intervention }\end{array}$ \\
\cline { 2 - 3 } & Follow-up 2 & $\begin{array}{l}\text { Discuss her conditions and emotions after the } \\
\text { intervention and last follow-up; motivate the } \\
\text { participant }\end{array}$ \\
\hline
\end{tabular}

The intervention program was planned for four sessions. However, an additional meeting was required to measure improvement maintenance once the intervention. Therefore, the intervention program was held in six sessions spread over a 3-month period. Sessions were scheduled at the convenience of the participant. Each session lasted approximately $120 \mathrm{~min}$. After completing the fourth session, the participant attended follow-up sessions 2 weeks and 2 months later to ensure the participant would be able to maintain her improved condition, especially during the crucial fifth semester and period and during her internship, wherein she had to adjust to the new setting.

\section{Analysis}

The effectiveness of this program was analyzed using quantitative and qualitative methods. Quantitative data analysis was conducted by comparing the percentage score from the beginning and the end sessions. We used a Friedman test to determine the statistical significance of the intervention. In addition, the behavioral checklist was analyzed quantitatively to check the effectiveness of the program. Qualitatively, the researcher also analyzed the participant's progress based on her statements, emotions, and behaviors. Qualitative data analysis was also conducted using data from the activity sheets and journals to identify her thoughts and emotions.

\section{Results}

The results of the research indicate acceptance of the study hypotheses stating that CBT is an effective treatment for improving self-acceptance and decreasing stress responses. Table 5 illustrates the results of the measurements obtained from the research.

Table V. Comparison of the Participant's Achievement

\begin{tabular}{|c|c|c|c|}
\hline Session & $\begin{array}{c}\text { Detail } \\
\text { (Indicators) }\end{array}$ & Beginning of Session & End of Session \\
\hline Session 1 & $\begin{array}{l}\text { The participant } \\
\text { knows her potential }\end{array}$ & $\begin{array}{l}\text { The participant does } \\
\text { not know her potential } \\
\text { Score }=\mathbf{0} / \mathbf{2}\end{array}$ & $\begin{array}{l}\text { The participant knows her } \\
\text { potential } \\
\text { Score }=\mathbf{2} / \mathbf{2}\end{array}$ \\
\hline Session 2 & $\begin{array}{l}\text { The participant } \\
\text { understands her } \\
\text { current condition }\end{array}$ & $\begin{array}{l}\text { The participant knows } \\
\text { a few things about her } \\
\text { current condition } \\
\text { Score }=1 / 2\end{array}$ & $\begin{array}{l}\text { The participant knows her } \\
\text { current condition well } \\
\text { Score }=\mathbf{2} / \mathbf{2}\end{array}$ \\
\hline \multicolumn{2}{|l|}{ Score } & $2 / 4(25 \%)$ & $4 / 4(100 \%)$ \\
\hline Session 3 & $\begin{array}{r}\text { participant } \\
\text { herself }\end{array}$ & $\begin{array}{l}\text { The participant views } \\
\text { herself negatively }\end{array}$ & $\begin{array}{l}\text { The participant } \\
\text { herself positively }\end{array}$ \\
\hline
\end{tabular}




\begin{tabular}{|c|c|c|c|}
\hline & positively & Score $=0 / 2$ & Score $=2 / 2$ \\
\hline & $\begin{array}{l}\text { The participant has } \\
\text { positive thoughts } \\
\text { about what other } \\
\text { people think of her }\end{array}$ & $\begin{array}{l}\text { The participant has } \\
\text { negative thoughts } \\
\text { about what other } \\
\text { people think of her } \\
\text { Score }=\mathbf{0} / \mathbf{2}\end{array}$ & $\begin{array}{l}\text { The participant has positive } \\
\text { thoughts about what other } \\
\text { people think of her } \\
\text { Score }=\mathbf{1} / \mathbf{2}\end{array}$ \\
\hline \multicolumn{2}{|l|}{ Score } & $0 / 4(0 \%)$ & $3 / 4(75 \%)$ \\
\hline \multirow[t]{2}{*}{ Session 3} & $\begin{array}{l}\text { The participant } \\
\text { understands the } \\
\text { basic premises of } \\
\text { CBT }\end{array}$ & $\begin{array}{l}\text { The participant does } \\
\text { not understand the } \\
\text { basic premises of } \\
\text { CBT } \\
\text { Score }=\mathbf{0} / \mathbf{2}\end{array}$ & $\begin{array}{l}\text { The participant understands } \\
\text { the basic premise of CBT } \\
\text { quite well } \\
\text { Score }=\mathbf{1} / \mathbf{2}\end{array}$ \\
\hline & $\begin{array}{l}\text { The participant is } \\
\text { aware of her } \\
\text { irrational thoughts } \\
\text { about herself and } \\
\text { others }\end{array}$ & $\begin{array}{l}\text { The participant is } \\
\text { somewhat aware of } \\
\text { her irrational thoughts } \\
\text { about herself and } \\
\text { others } \\
\text { Score }=\mathbf{1 / 2}\end{array}$ & $\begin{array}{l}\text { The participant is aware of } \\
\text { her irrational thoughts about } \\
\text { herself and others } \\
\text { Score }=\mathbf{2} / \mathbf{2}\end{array}$ \\
\hline \multicolumn{2}{|l|}{ Score } & $1 / 4(25 \%)$ & $3 / 4(75 \%)$ \\
\hline \multirow[t]{4}{*}{ Session 4} & $\begin{array}{l}\text { The participant has } \\
\text { realistic and positive } \\
\text { thoughts about } \\
\text { herself }\end{array}$ & $\begin{array}{l}\text { The participant has } \\
\text { irrelevant and } \\
\text { negative thoughts } \\
\text { about herself } \\
\text { Score = 0/4 }\end{array}$ & $\begin{array}{l}\text { The participant has realistic } \\
\text { and positive thoughts about } \\
\text { herself } \\
\text { Score }=\mathbf{2} / \mathbf{4}\end{array}$ \\
\hline & $\begin{array}{l}\text { The participant has a } \\
\text { realistic and positive } \\
\text { thought about others }\end{array}$ & \begin{tabular}{lr}
\multicolumn{2}{l}{ The participant has an } \\
irrelevant \\
negative \\
about others \\
Score $=\mathbf{0} / \mathbf{4}$
\end{tabular} & $\begin{array}{l}\text { The participant has a } \\
\text { relevant and positive } \\
\text { thought about others } \\
\text { Score }=\mathbf{1} / \mathbf{4}\end{array}$ \\
\hline & $\begin{array}{l}\text { The participant feels } \\
\text { positive about } \\
\text { herself }\end{array}$ & $\begin{array}{l}\text { The participant feels } \\
\text { negative about herself } \\
\text { Score }=\mathbf{0} / \mathbf{4}\end{array}$ & $\begin{array}{l}\text { The participant feels } \\
\text { positive about herself } \\
\text { Score }=\mathbf{2 / 4}\end{array}$ \\
\hline & $\begin{array}{l}\text { The participant is } \\
\text { motivated to solve } \\
\text { her current problems }\end{array}$ & $\begin{array}{l}\text { The participant is not } \\
\text { motivated to solve her } \\
\text { current problems } \\
\text { Score }=\mathbf{0} / \mathbf{4}\end{array}$ & $\begin{array}{l}\text { The participant is motivated } \\
\text { to solve her current } \\
\text { problems } \\
\text { Score }=\mathbf{1} / \mathbf{4}\end{array}$ \\
\hline \multirow{3}{*}{\multicolumn{2}{|c|}{$\begin{array}{l}\text { Score } \\
\text { Total score } \\
\text { Score difference }\end{array}$}} & $0 / 8(0 \%)$ & $6 / 8(75 \%)$ \\
\hline & & $3 / 20(15 \%)$ & $13 / 20(65 \%)$ \\
\hline & & $50 \%$ & \\
\hline
\end{tabular}

From Table 5, we can see improvements in all indicators after the completion of the intervention program. The participant's performance score increased from $15 \%$ in the beginning session to $65 \%$ at the last session.

This study found that the intervention program also positively affected the participant's selfacceptance and stress response. Tables 6 and 7 illustrate the results of the measurements obtained from the behavioral checklist. 
Table VI. Self-Acceptance Results

\begin{tabular}{|c|c|c|c|c|c|c|}
\hline \multirow[t]{2}{*}{ Self-Acceptance Characteristics } & \multicolumn{6}{|c|}{ Session } \\
\hline & 1 & 2 & 3 & 4 & $F U 1$ & $F U 2$ \\
\hline $\begin{array}{l}\text { Belief that one's self-worth is bestowed by virtue } \\
\text { of being human }\end{array}$ & 2 & 3 & 3 & 3 & 4 & 4 \\
\hline Belief that no one is worth more than anyone else & 2 & 2 & 3 & 2 & 2 & 4 \\
\hline $\begin{array}{l}\text { Tendency to set goals based on a pursuit of } \\
\text { intrinsic satisfaction and enjoyment rather than on } \\
\text { enhancement of self-worth }\end{array}$ & 1 & 1 & 2 & 3 & 2 & 3 \\
\hline General avoidance of the tendency to self-rate & 1 & 1 & 2 & 3 & 2 & 3 \\
\hline $\begin{array}{l}\text { Objective awareness of one's strengths but } \\
\text { without a global appraisal on the basis of these } \\
\text { strengths and limitations }\end{array}$ & 1 & 1 & 2 & 3 & 3 & 4 \\
\hline $\begin{array}{l}\text { Tendency to respond to failure and negative } \\
\text { feedback with some unhappiness about thwarted } \\
\text { goals, but not as indicative of lower self-worth }\end{array}$ & 1 & 1 & 2 & 2 & 3 & 4 \\
\hline $\begin{array}{l}\text { Tendency to respond to failure and negative } \\
\text { feedback as informative about areas for } \\
\text { behavioral improvement }\end{array}$ & 1 & 2 & 3 & 3 & 3 & 4 \\
\hline $\begin{array}{l}\text { Tendency to respond to success and positive } \\
\text { feedback as informative, but not with a sense of } \\
\text { being a better person because of the success }\end{array}$ & 2 & 2 & 3 & 3 & 3 & 4 \\
\hline $\begin{array}{l}\text { Sense of self-worth independent of other's } \\
\text { approval }\end{array}$ & 1 & 1 & 2 & 2 & 3 & 3 \\
\hline $\begin{array}{l}\text { General avoidance of the tendency to compare } \\
\text { one's worth with others }\end{array}$ & 1 & 1 & 2 & 2 & 3 & 4 \\
\hline
\end{tabular}

The table above shows improvement in the participant's self-acceptance in each intervention and the follow-up session. A nonparametric Friedman test of difference among repeated measures was conducted and rendered a chi-square value of 41.94. Therefore, the results were statistically significant $(\mathrm{p}<0.01)$.

Table VII. Stress Responses Results

\begin{tabular}{|c|c|c|c|c|c|c|c|}
\hline \multirow{2}{*}{\multicolumn{2}{|c|}{ Stress Response Characteristics }} & \multicolumn{6}{|c|}{ Session } \\
\hline & & 1 & 2 & 3 & 4 & FU1 & FU2 \\
\hline $\begin{array}{l}\text { Physical } \\
\text { response }\end{array}$ & $\begin{array}{l}\text { Involves the nervous system and } \\
\text { endocrine system (increased blood } \\
\text { pressure, heart rate, pulse rate, skin } \\
\text { conductivity, and respiration) }\end{array}$ & 4 & 3 & 2 & 2 & 2 & 1 \\
\hline $\begin{array}{l}\text { Emotional } \\
\text { response }\end{array}$ & $\begin{array}{l}\text { Fear, anxiety, enthusiasm, shame, anger, } \\
\text { depression, and denial }\end{array}$ & 3 & 3 & 2 & 2 & 2 & 1 \\
\hline $\begin{array}{l}\text { Cognitive } \\
\text { response }\end{array}$ & $\begin{array}{l}\text { Lack of concentration and disturbances } \\
\text { in the cognitive processes (easily } \\
\text { distracted, repetitive, and thinking } \\
\text { irrelevant thoughts) }\end{array}$ & 4 & 3 & 2 & 2 & 1 & 1 \\
\hline $\begin{array}{l}\text { Behavioral } \\
\text { response }\end{array}$ & $\begin{array}{l}\text { Fight (aggressive response to stress) or } \\
\text { flight (social withdrawal, withdrawal } \\
\text { through drugs or alcohol) }\end{array}$ & 4 & 3 & 2 & 2 & 1 & 1 \\
\hline
\end{tabular}


Table 7 shows the participant's decrease in stress response. A nonparametric Friedman test of difference among repeated measures was conducted and rendered a significant chi-square value of $41.94(p<0.01)$.

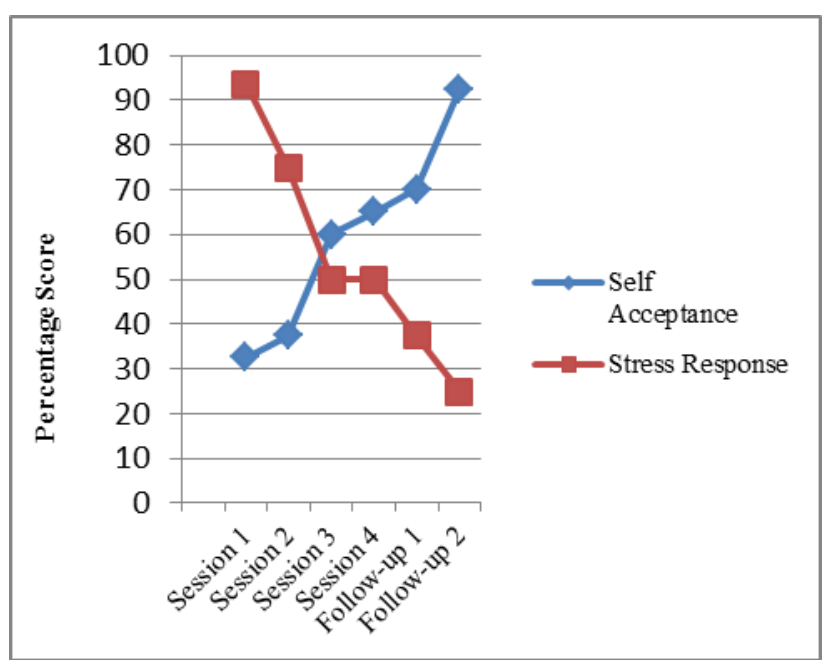

Fig.1. Participant's result of self-acceptance and stress response

The qualitative data analysis results for the participant's self-acceptance and stress response showed an improvement. The explanation of the results is as follows:

1. Before the intervention, the participant found difficulties in recognizing positive aspects of herself. Through the CBT approach, the participant was directed to focus on her strengths and positive sides. After the intervention, she felt more confident and realized that she had a lot of potentials.

2. The participant had not been able to accept situations in the past, which then led to negative automatic thoughts. The brief CBT helped the participant find alternative thoughts to enable her to accept those situations as experiences in the past.

3. The participant had negative thoughts about people's judgments of her performance. The CBT intervention helped her understand that everyone makes mistakes, including herself. After the session, she began to open up with the people around her and decided to be less worried about negative judgments from others. Moreover, the participant's emotions became more positive towards herself and others.

4. The participant's stress level made it difficult for her to focus on learning, and this affected her academic achievements. Through CBT, the participant developed appreciation for her cognitive abilities and learning potential. This motivated the participant to increase her GPA score and encouraged her to focus more on her studies to enhance her academic performance.

The participant's problems also affected her physical condition. Through the CBT treatment, she learned coping strategies and relaxation techniques that improved her physical conditions as her stress responses decreased. 


\section{Discussion and Conclusion}

The current study examines the effectiveness of CBT treatment in improving self-acceptance and reducing stress in a college student. Based on the research findings, we concluded that the CBT intervention significantly improved the participant's self-acceptance and decreased her stress. By the end of the intervention, the participant noted that she made significant progress towards her goals. She knew her potential and felt confident. The participant was better able to accept and work with situations that previously influenced her negative thoughts (e.g., "I am being judged by others!")

The participant learned to develop a positive thought to counteract the negative one and improve her emotions and behaviors. She began to open up with the people in her social environment and stopped worrying about negative judgments from others. As a result, the participant's self-acceptance increased. The result is in line with other studies, which have shown that self-acceptance can be improved by CBT treatment (Branch \& Wilson, 2007; Cully \& Teten, 2008). Improvement in self-acceptance allows individuals to more willingly accept their situation and be realistic in their views and adaptive to their environment, which, in turn, improves their behaviors and modulates their emotions (Linley \& Joseph, 2004, pp. 11-21; Pramono \& Astuti, 2017).

Through her CBT treatment, the participant found a way to work with her problems, and she became increasingly motivated to do so. Moreover, she was able to regulate her emotions, which decreased her stress level. The participant's increased motivation and improved learning performance ensured that by the fifth semester of school, she will be able to focus on her studies and improve her grades. This result shows that CBT approach can reduce academic stress and enhance academic performance. The findings of the present study are consistent with those in previous studies related to CBT and stress conditions in an educational setting (Khanekeksi, 2014; Sharma, Shrivastava, Malholtra, Singh, \& Singh, 2010).

The effectiveness of this study intervention is based on the establishment of a good rapport between the researcher and the participant. The participant's openness was helpful to the effectiveness of the treatment. Moreover, the participant's willingness to change increased her commitment to the intervention, and her intellectual understanding of the program and her self-reflection also helped her to be successful in the CBT treatment. These findings are in line with Cully and Teten (2008), who mentioned that strong motivation to change, time commitment, cognitive functioning, and educational level were the things to consider in evaluating whether the brief CBT is suitable for a client.

This study shows that CBT treatment had a positive effect on the participant. However, this research was not spared from limitations. For example, the use of the single-case study design limited the possibility of seeing how this intervention would affect other college students who lack self-acceptance. The study may not be easily generalizable. Therefore, in the future, we should consider the differences in characteristics and needs of various types of students and 
use information based on that to modify or redesign the program. Another limitation of this study is the lack of self-report measures to assess the self-acceptance and the respondent's subjective experience of stress. Researchers should consider using self-acceptance and stress self-report instruments for college students in future studies.

Nevertheless, the results of this study could be useful to address future topics related to CBT treatment, self-acceptance, and college student stress.

\section{References}

Brecht, G. (2000). Mengenal dan Menanggulangi Stres. Jakarta: Prent Hallindo.

Branch, R., \& Wilson, R. (2007). Cognitive Behavioural Therapy for Dummies. England: John Wiley \& Sons, Ltd.

Chamberlain, J. M. (1999). An empirical test of rational-emotive behavior therapy's unconditional selfacceptance theory. Washington, D.C: Faculty of the College of Arts and Sciences of America University.

Chamberlain, J. M., \& Haaga, D. A. F. (2001). Unconditional self-acceptance and psychological health. American University: Journal of Rational-Emotive \& Cognitive Behavior Therapy, 19.

Cully, J. A., \& Teten, A. L. (2008). A Therapist's Guide to Brief Cognitive Behavioral Therapy. Department of Veterans Affaris South Central MIRECC, Houston.

Dexter, L. R., Huff, K., Rudecki, M., \& Abraham, S. (2018). College student's stress coping behaviors and perception of stress-effects holistically. The International Journal Studies in Nursing, 3, 1-6.

Dy, M.R., Espiritu-Santo, K., Ferido, M.P., \& Sanchez. R. D. (2015). Stressors and stress responses of Filipino college students. Asia Life Science, 24, 737-759.

Farmer, R. F., \& Chapman, A. L. (2016). Behavioral Intervention in Cognitive Behavior Therapy. Practical Guidance for Putting Theory into Action. USA: American Psychological Association.

Flett, G. L., Besser, A., Davis, R.A., \& Hewitt, P. L. (2003). Dimensions of Perfectionism, Unconditional SelfAcceptance, and Depression. Journal of Rational-Emotive and Cognitive-Behavior Therapy, 21, 119138.

Gravetter, F.J., \& Cleland. C.J. (2012). Research methods for the behavioral sciences (third edition). USA: Wadsworth Cengage Learning.

Handayani, R. (2004). Gambaran Stres dan Perilaku Coping Terhadap Pemenuhan Kebutuhan Ekonomi pada Orangtua yang Memiliki Anak Autis (Undergraduate Thesis). Universitas Katolik Atma Jaya, Jakarta, Indonesia.

Heriyadi, A. (2013). Meningkatkan Penerimaan Diri (Self-Acceptance) Siswa Kelas VIII Melalui Konseling Realita di SMP Negeri 1 Bantarbolang Kabupaten Malang Tahun Ajaran 2012/2013 (Undergraduate mini thesis). Universitas Negeri Semarang, Semarang.

Hurlock, E. B. (1974). Personality Development. New Delhi: Mc Graw Hill, Inc.

Khanehkeshi, A. (2014). Effectiveness of Cognitive Behavior Therapy on Academic Stress Among High School Students. Indian Journal of Fundamental and Applied Life Sciences, 4, 681-694. Retrieved from http://www.cibtech.org/sp.ed/jls/2014/03/JLS-091-S3-096-ALI-EFFECTIVENESS.pdf

Linley, P.A. \& Joseph, S. (2004). Positive change following trauma and adversity: a review. US National Library of Medicine National Institutes of Health, 17, 11-21.

Macinnes, D. L. (2006). Self-esteem and Self-acceptance: An examination into their relationship and their effect on psychological health. Journal of Psychiatric and Mental Health Nursing, 13, 483-489.

McGhee, M. (2016). Self-acceptance Training. Retrieved from http://www.acceptanceandintegrationtraining.com.

Pariat, L., Rynjah. A., \& Kharjana, M.G. (2014). Stress levels of college students: Interrelations between stressors and coping strategies. Journal of Humanities and Social Science, 19, 40-46.

Pitt, A., Oprescu, F., Tapia, G., \& Gray, M. (2018). An exploratory study of students' weekly stress levels and sources of stress during the semester. Active Learning in Higher Education, 19(1), 61-75.

Powell, J. S. J. (1992). 10 Laku Hidup Bahagia. Yogyakarta: Kanisius. 
Regehr, C., Glancy, D., \& Pitts, A. (2013). Interventions to reduce stress in university students: A review and meta-analysis. Journal of Affective Disorders, 148, 1-11.

Ross, S. E., Niebling, B. C., \& Heckert, T. M. (1999). Source of stress among college students. Pramono, R. B., \& Astuti, D. (2017). Cognitive Behavioral Therapy as an Effort to Improve Self-Acceptance of Adolescent in Orphanage. The Open Psychology Journal, 10, 161-169. College Student Journal, 33, 312317. Retrieved from http://psycnet.apa.org/record/1999-03006-021

Sharma, V., Shrivastava, S., Malholtra, S., Singh, R., \& Singh, T. B. (2010). Yoga and cognitive behavior techniques for academic stress and mental wellbeing among school students. Delhi Psychiatry Journal, 13.

Straud, C. L., \& McNaughton-Cassill. M. (2018). Self-blame and stress in undergraduate college students: The mediating role of proactive coping. Journal of American College Health, 1-12.

Taylor, S.E. (2012). Health Psychology ( $8^{\text {th }}$ ed.). New York: McGraw- Hill.

Warastri, A. (2017). Effectiveness of Cognitive Behavior Therapy towards Self-Acceptance Students in BPOPKRI 2 Yogyakarta Senior High School. Jurnal Ilmu Pendidikan, Psikologi, Bimbingan dan Konseling, 7(1), 1-6.

Widiantoro, W. (2015). Meningkatkan Pemahaman Penerimaan Diri Melalui Permainan "Menggambar Jari" sebagai upaya meningkatkan Kesejahteraan Psikologis Pada Warga Binaan. Fakultas Psikologi Universitas Proklamasi 45 Yogyakarta: Seminar Psikologi \& Kemanusiaan. Retrieved from http://mpsi.umm.ac.id/files/file/131-135\%20FX.pdf 